\title{
4. The Right to Participate: Revisiting Roach and Rowe
}

\author{
Glenn Patmore ${ }^{1}$
}

As is well known, the Constitution does not refer to the words 'democracy', 'representative democracy', 'representative government' or 'referendum democracy'. Nonetheless the High Court has been willing to imply recognition of these foundational principles. Most of the cases have considered the implied freedom of political communication. More recently, the High Court recognised a constitutional protection of a right to vote and to participate in membership of the political community. ${ }^{2}$

This is a significant development in the jurisprudence of the High Court, but it remains a relatively limited conception of the right to participate. ${ }^{3}$ This chapter outlines a broader conception - the right to participate in collective decision-making. The chapter therefore examines and expands upon the High Court's more confined approach. It explains how this latter right is protected by the Constitution and legislation, how it operates in practice, and how it is recognised in political traditions.

For citizens to make collective decisions there must be a set of political institutions and rules which determine 'who is authorised to make' those decisions and 'which procedures ought to be applied'. ${ }^{4}$ Insofar as that power 'is authorized by the basic law of the constitution, [it] becomes a right' for all qualified citizens. ${ }^{5}$ Thus the capacity to exercise the power to make political decisions is an entitlement recognised as a basic norm of the Constitution. There can be little doubt that the legal authorisation of participation in collective decision-making is an entitlement recognised in law. The view that the Constitution confers

\footnotetext{
1 g.patmore@unimelb.edu.au. I wish to thank for their assistance, Mr Tom Appleby, Mr Benjamin Hine and Ms Candice Parr who read material to me and provided research assistance. Their work was much appreciated. A special debt is owed to Ms Sarah Shrubb who read the paper and offered comments. Special thanks must also be given to the Melbourne Law Research Service.

2 Roach v Electoral Commissioner (2007) 233 CLR 162; Rowe v Electoral Commissioner (2010) 243 CLR 1. For a similar view in the US, see Louis Fisher and Katy J Harriger, 'Political Participation' in American Constitutional Law (Carolina Academic Press, 8th ed, 2009) 949.

3 This is perhaps inevitable given the judicial duty only to decide matters brought before the court.

4 Norberto Bobbio, The Future of Democracy (Roger Griffin trans, University of Minnesota Press, 1987) 24.

5 ibid.
} 
rights on all the people has also been recently recognised. In Rowe, French CJ noted that the requirement of a direct choice in ss 7 and 24 of the Constitution 'confers rights on "the people of the Commonwealth" ${ }^{6}$ as a whole'. ${ }^{7}$

This chapter has two parts. The first part explains the legal rules and political practices that provide for participation by citizens in collective decision-making. Drawing upon the democratic literature, the chapter identifies the basic legal rules necessary for democracy to function. ${ }^{8}$ It also briefly refers to the history of the democratisation of Westminster government and highlights some judicial opinion that has provided support for a broad understanding of constitutional democracy. Secondly, the chapter examines how these legal rules and political practices are and may be better recognised in the law, including in the Australian Constitution, constitutional conventions and legislation. It also considers the recent High Court decisions referring to the constitutional protection of the right to vote and to participate in the political life of the community.

\section{Rights and freedoms to make collective decisions}

\section{Right to participate}

Since the late 18th century, citizens have been regarded as having a 'right to participate in the determination of the collective will through the medium of elected representatives'. ${ }^{9}$ By the end of the 19th century, citizens were regarded as having a right to participate in referendums and plebiscites. Today, the right to participate can be expressed as three principles, which provide the procedure for making the most important collective decisions and find expression in the Australian Constitution. The first principle is that electors directly choose representatives in periodic elections. This principle is recognised in the Australian Constitution, as the High Court explained in Lange:

6 Langer $v$ Commonwealth (1996) 186 CLR 302, 343 per McHugh J.

7 Rowe $v$ Electoral Commissioner (2010) 243 CLR 1, 12.

8 My analysis of the Australian Constitution and electoral legislation draws upon elite theories of democracy which are well known to political scientists. While this form of democracy has been criticised as limited, it is nonetheless useful in providing a focus on collective decision-making recognised by the law. See for example Henry Mayo, An Introduction to Democratic Theory (Oxford University Press, 1960) and David Held 'Competitive Elitism and the Technocratic Vision' in Models of Democracy (Polity, 3rd ed, 2006) 125.

9 Norberto Bobbio, Democracy and Dictatorship (Polity, 1989) 144; David Held, Models of Democracy (Polity, 3rd ed, 2006) 94 . 
Sections 7 and 24 of the Constitution, read in context, require the members of the Senate and the House of Representatives to be directly chosen at periodic elections by the people of the States and of the Commonwealth respectively. ${ }^{10}$

This principle is seen as the one indispensable requirement of modern democracies, ${ }^{11}$ because a direct choice provides for popular control of representatives. As Gummow J explained in McGinty: 'What is necessary is the broadly identified requirement of ultimate control by the people, exercised by representatives who are elected periodically'.$^{12}$

Second, once elected, representatives alone make legislative ${ }^{13}$ and executive ${ }^{14}$ decisions $^{15}$ on behalf of citizens. ${ }^{16}$ In Westminster systems like Australia's, Ministers of State exercise executive power, which is the final power of political decision. In other words, they make public policy decisions. They must also be members of Parliament, and are accountable to it. ${ }^{17}$ As Mayo pointed out many years ago:

On the whole, no democratic system operates on the principle that voters directly decide public policies at elections. The control over policy is much more indirect - through the representatives. ${ }^{18}$

Of course Ministers are responsive to the views of electors, since 'popular influence over policy occurs day in day out' ${ }^{19}$ This influence may take different forms, such as through the popular media, community and interest groups, elites, and even state parliamentarians. Indeed the effect of popular influence and control is contemplated by the very system of responsible government. This principle, amongst other things, requires that members of the executive are responsible to Parliament and ultimately to the people, at an election. As

\footnotetext{
10 Lange $v$ Australian Broadcasting Corporation (1997) 189 CLR 520, 557.

11 Mayo, above n 8; Bobbio, above $\mathrm{n} 4$.

12 McGinty $v$ Western Australia (1990) 186 CLR 140, 285.

13 Legislative power most obviously refers to the power of a Parliament to enact legislation. Members and senators for instance have the power to vote on legislation and participate in the process and procedures of the legislature. See, for example, the Australian Constitution ss 23 and 40.

14 Executive power refers to the power of the executive to administer the law and to manage the government, especially government departments. Ministers administer government departments and make collective decisions in cabinet. See, for example, Australian Constitution ss 61 and 64.

15 These powers are conferred solely on office holders, such as senators, members and ministers. The Queen and Governor-General, as members of the executive, do not make political decisions according to constitutional conventions.

16 See Suri Ratnapala and Jonathan Crowe, Australian Constitutional Law: Foundations and Theory (Oxford University Press, 3rd ed, 2012) 37.

17 The principle of responsible government inter alia requires that members of the executive are responsible to Parliament and ultimately to the people at an election. The executive includes Ministers, who must sit in Parliament. See the Australian Constitution ss 61 and 64 .

18 Mayo, above n 8, 61.

19 ibid.
} 
the court in Lange explained, 'the attitudes of electors to the conduct of the Executive may be a significant determinant of the contemporary practice of responsible government' ${ }^{20}$

The third principle is that electors directly make policy decisions through the occasional use of referenda and plebiscites. In plebiscites, the electors are asked to vote on a question of national importance, whereas in a referendum to amend the Australian Constitution, ${ }^{21}$ electors are asked to vote on a law that is referred to them for their final approval. ${ }^{22}$ When voting in referendums to change the Constitution, electors make a policy choice; they exert control over the final decision whether or not to alter the Constitution. Even though the question is framed by the Federal Parliament through a referendum bill, it is not simply a choice offered to the people, but one in which they are typically engaged throughout the entire process of change. The Prime Minister and Cabinet usually initiate the constitutional change, the question to be asked is formulated and approved by the Parliament, opportunities for participation and discussion are created and, ultimately, the people are given their say. While the third principle is regarded as an exception to the second principle of participation, it is, as we have seen, more complex. There is a vital intersection between representative and referendum democracy. The Parliament proposes and the electors decide.

The right to participate, expressed as three principles, helps us understand that the Constitution provides legal entitlements to participate in collective decisions. There are also more specific rights and limitations recognised in the Constitution and legislation.

\section{The democratic rights}

The so-called democratic rights or the 'rights of representatives' ${ }^{23}$ were developed through struggles over several centuries, but crystallised in the 19th century, in the well-known Chartist movement in the United Kingdom. ${ }^{24}$ Their Charter had six basic points that were included in petitions to the UK Parliament

\footnotetext{
20 Lange v Australian Broadcasting Corporation (1997) 189 CLR 520, 559.

21 Australian Constitution s 128.

22 As Professor Orr notes: 'Terminology is often loosely used in this area.' Orr defines a referendum as 'a binding poll: one that is a necessary part of some legislative or constitutional process'. Conversely, he employs the term plebiscite 'for a poll that is essentially indicative only'. See Orr, 'The Conduct of Referenda and Plebiscites in Australia: A Legal Perspective' (2000) 11 Public Law Review 117.

23 Some of these rights are also explicitly recognised in other Constitutions such as the Canadian Constitution (1982): Canada Act 1982 (UK) ('Canadian Charter of Rights and Freedoms').

24 'Chartism', in John Cannon (ed), Oxford Companion to British History (Oxford University Press, 2002) 193; Dorothy Thompson, The Chartists (Temple Smith, 1984).
} 
in 1839, 1842 and 1848. Five of those points evolved into five rules: universal adult suffrage, the secret ballot, ${ }^{25}$ no property qualification to vote or to sit in Parliament, ${ }^{26}$ payment of members of Parliament, ${ }^{27}$ and equal electorate sizes. ${ }^{28}$

The sixth point of the Charter, demanding annual elections to Parliament, was never implemented in the United Kingdom; nor has it been implemented in Australia. But the requirement for periodic elections has endured and reflects the view that representatives should be regularly accountable to the electorate.

The Chartist movement influenced the development of colonial democracy in Australia and the British Empire. As Justice Crennan explained in an extrajudicial speech, the struggle for 'full and fair representation', especially relating to manhood suffrage, became what is known as the 'imperial framework' and 'reveals the values which lie behind, and are expressed in the Constitution, in the phrase "directly chosen by the people"". ${ }^{29}$

As noted, the first five points demanded by the Chartists are now included in either Australian electoral legislation or the Australian Constitution, and in UK electoral legislation. They are concerned with the authorisation of those who are to make collective decisions, providing who shall choose and be chosen as representatives (according to the universal franchise), how they shall be chosen (through a secret ballot from electorates of equal size), and with removing limits on that choice based on property and wealth qualifications. Overall, the law authorises the whole people to participate in making collective decisions and confers legal rights 'to participate directly or indirectly in the making' of those decisions. ${ }^{30}$ But more is required for democracy to function.

\section{Fundamental freedoms}

There is a third condition necessary for collective decisions to be made: electors and representatives must be offered real alternatives, and have the freedom to choose between them. ${ }^{31}$ This condition is guaranteed by the fundamental

\footnotetext{
25 Commonwealth Electoral Act 1918 (Cth) s 323.

26 Various property qualifications lowered or repealed from 1851 onwards. No longer applicable under federal law.

27 Commonwealth of Australia Constitution Act 1900 (UK) s 48.

28 Commonwealth Electoral Act 1918 (Cth) s 56.

29 Justice Susan Crennan, 'Reflections on Sections 7 and 24 of the Constitution' (Speech delivered at Gilbert \& Tobin Centre of Public Law, Constitutional Law Dinner, New South Wales, 8 February 2008). In the later decision of Rowe, her Honour, echoing some of her earlier views in this speech, acknowledged that "“choice by the people" of parliamentary representatives is a constitutional notion signifying individual citizens having a share in political power through a democratic franchise'. This view was expressly agreed with by Gummow and Bell JJ in that case, Rowe v Electoral Commissioner (2010) 243 CLR 1, 48.

30 Bobbio, above n 4, 25.

31 ibid.
} 
freedoms of speech, association and assembly. ${ }^{32}$ These freedoms draw on the philosophical tradition of the inviolable rights of the individual, as expressed in the French and American revolutions and in contemporary human rights movements. Whatever be their philosophical justifications, though, these freedoms are regarded as the necessary preconditions for the predominantly procedural rules of democracy to function effectively. ${ }^{33}$ These freedoms form the basis not only of the liberal state, but also of the democratic state, and when 'political liberties and the legitimate opposition are gone, so, too, is democracy' ${ }^{34}$

In sum, these procedural rules are regarded as the preconditions for the game, not the game itself. ${ }^{35}$ What, then, is the game? The game is the elite competition for power which occurs in Western representative democracies. The competition takes place not only during elections, of course, but through the whole term of the Parliament. Representative democracy is by definition elite, confined to only the small number of individuals who are elected as representatives. The game itself also imposes responsibilities for representatives in a democracy.

\section{Responsibilities of representatives}

Mayo recognises three responsibilities as forming the rules of the game for representatives. ${ }^{36}$ First, the government, formed by the majority of representatives, makes its policy decisions subject to the existence of the fundamental freedoms. These freedoms limit the capacity of the government to silence the opposition, the critics and those who dissent. It is axiomatic that in Western democracy there is a government and there is an opposition. Political liberties may not be removed by the government within or outside Parliament. This does not mean that governments may not coerce the opposition into obedience to law, nor ill-treat their opponents. Rather, the fundamental freedoms guarantee the opportunity for the opposition and the dissenters to be heard, to protest and to organise. ${ }^{37}$ Thus this rule is an inhibition on majority rule.

Second, the opposition will obey the law, even though it might be difficult because the law is disliked. ${ }^{38}$ While obeying the law, oppositions habitually work to change the policy and ultimately to change the government and become

\footnotetext{
32 ibid.

33 ibid.

34 Mayo, above n 8, 68.

35 Bobbio, above $\mathrm{n} 4,25$.

36 Mayo, above n 8, 68.

37 ibid.

38 This is subject to circumstances when there are opportunities for civil disobedience. Opportunities for civil disobedience raise controversial and complex issues of legal obligation. See Lord Lloyd of Hampstead and MDA Freeman, Lloyd's Introduction to Jurisprudence (Law Book Co Ltd, 5th ed, 1985); Ronald Dworkin, Taking Rights Seriously (Harvard University Press, 1978) ch 7-8; MR Macguigan, 'Obligation and Obedience' in Pennock and Chapman (eds), Political and Legal Obligations (Nomos XII, 1970).
} 
a majority — but only by peaceful means. ${ }^{39}$ Third, when there is a change of government the new government is subject to the same fundamental freedoms and the new opposition is bound by the same obligations. ${ }^{40}$ As Mayo explains, ' $\mathrm{t}$ ] he minority also agrees beforehand that they, too, will extend the same political freedoms and follow the same rules of the game should they arrive in the seats of office'. ${ }^{41}$ The game continues again, with new actors and office holders, according to these rules.

These responsibilities are regarded as necessary for the continuity of democracy. There are of course other social conditions necessary for the peaceful transfer of power and functioning of democracy. ${ }^{42}$ However, as Mayo says, these three rules represent the 'formal conditions' necessary to be met 'for majorities and minorities in the legislature if democracy is to work at all'. ${ }^{43}$ Mayo regards these rules respectively as an inhibition, an obligation and an agreement. In constitutional discourse they would be regarded as constitutional practices or traditions. These responsibilities can also be implied from the express constitutional provisions authorising representatives to make legislative and executive decisions. As these responsibilities may be implied from the text of the Constitution, each may be regarded as a constitutional obligation. ${ }^{44}$

\section{Recognition in law of the rules for collective decision-making}

I have examined the right to participate in collective decision-making by explaining the key legal rules, principles and norms upon which the right rests. These provide who is authorised to make collective decisions and the procedures to be applied. But how, you might ask, are these rules recognised in law? In passing, I have already briefly indicated how these rules are acknowledged in law, but some further explanation is required. I address this topic in two ways: first, by briefly analysing how the rules for making collective decisions are recognised in traditional sources of law such as the Constitution, constitutional conventions and legislation; and second, by examining how legislative rights are recognised and may become protected by the Constitution.

\footnotetext{
39 Mayo, above n 8, 32.

40 ibid.

41 ibid 68.

42 ibid.

43 ibid.

44 Mayo identifies a problem here, where a minority party uses political freedom to abolish democracy itself. This problem is addressed in contemporary literature. See for example S Issacharoff, 'Fragile Democracies' (2007) 120(6) Harvard Law Review 1406-23
} 


\section{Recognition in traditional sources of law of the rules for collective decision-making}

Democratic rights and freedoms are protected by the juridical state. This is the state which is governed not only sub lege — or under law — but also according to constitutional limits. ${ }^{45}$ The right to participate and the 'democratic rights' of representatives may be inferred from express provisions in the Constitution. Some are imposed as institutional obligations on the legislature: 'There shall be a session of the Parliament once at least in every year', for example. ${ }^{46}$ Others are expressed as rights of representatives: 'each member and senator ... shall receive an allowance of ${ }^{\prime}{ }^{47}$ and each member and senator 'shall have one vote', and 'questions arising ... shall be determined by a majority of votes' in the respective houses of Parliament. ${ }^{48}$ Some are expressed as individual rights and freedoms. The fundamental freedoms are typically recognised in constitutional bills of rights and statutory charters.

The rule that legislation must be passed subject to the fundamental freedoms receives explicit recognition where there is a statutory or constitutional bill of rights. ${ }^{49}$ In Australia, at the federal level, where there is no constitutional bill of rights, freedom of political communication has now been recognised as an implied limit under the Constitution. The freedom confers an immunity from the operation of legislative and executive power..$^{50}$ Other fundamental freedoms may also be recognised by the High Court. ${ }^{51}$

The responsibilities for representatives have for a long time been regarded as rules of political practice, and might be regarded as constitutional conventions. These are traditions, not rules of law. ${ }^{52}$ They enable the words of the Constitution to be understood in the context of rules induced from political practice. The conventions are principally concerned with the relationship between the Prime Minister, the Ministers and the Governor-General. ${ }^{53}$ The responsibilities for

\footnotetext{
45 Bobbio, above n 4, 25.

46 Australian Constitution s 6.

47 ibid s 48.

48 ibid s 23.

49 See for example Victorian Charter of Rights and Responsibilities Act 2006 (Vic) pt 2; those in the US Constitutional Amendment I; and Canadian Charter of Rights and Freedoms s 2.

50 Lange $v$ Australian Broadcasting Corporation (1997) 189 CLR 520.

51 McGinty $v$ the State of WA (1996) 186 CLR 140, 202; ACTV v Commonwealth (1992) 177 CLR 106, 231-32; Kruger v Commonwealth (1997) 190 CLR 1, 229; Wainohu v New South Wales (2011) 243 CLR 181, 230.

52 They are non-justiciable (that is, they are not capable of being settled by a court of law) and are often described as constitutional conventions. James Clarke, Patrick Keyzer and James Stellios, Hank's Constitutional Law: Materials and Commentary (LexisNexis, 2009) 1046-47. Breach of these rules may have real consequences for political actors, the Crown, the Ministers and the Parliament, who have responsibility for administering them. Clarke et al., Hank's Constitutional Law (LexisNexis, 2009) 1046.

53 Glenn Patmore, 'The Head of State Debate: A Response to Sir David Smith and Professor David Flint' (2012) 58(2) Australian Journal of History and Politics 251.
} 
representatives have not been expressly recognised as conventions in Australia. ${ }^{54}$ Nonetheless, they might be acknowledged as conventions in the same way that conventions were recognised by Gibbs CJ in FAI Insurance Ltd $v$ Winneke. ${ }^{55}$ In this case the question was whether or not the rules of natural justice applied to the Governor in Council. Gibbs CJ relied on the constitutional convention of responsible government to apply the rules of natural justice. His argument ran this way: the Governor in Council must act on the advice of Ministers, who are subject to the rules of natural justice. Therefore the rules of natural justice apply to the Governor in Council in exercising a statutory function. There was also no reason why the Governor in Council should not be subject to the rules of natural justice. ${ }^{56}$

Similarly, the principle of responsible government requires that the government be formed by the party which has the confidence of a majority of members in the lower house of Parliament. If there is to be a new majority or the majority is to be tested, the government must respect the conditions which allow a new majority to be formed. Accordingly, members of Parliament are subject to the responsibilities of representatives to obey the law and make decisions subject to the fundamental freedoms. ${ }^{57}$

Constitutional conventions are political practices or traditions subject only to political pressure. There is a difference in attitude towards conventions in Australia and Britain. For example, Marshall notes that 'the most obvious and undisputed convention of the British constitutional system is that Parliament does not use its unlimited powers of legislation in an oppressive and tyrannical way'.$^{58}$ In this way conventions act as an inhibition on the conduct of representatives in the United Kingdom. By contrast, in Australia such a convention has not always been followed. Conventions may be overridden by legislation, as they are not principles of law. Laws which have sought to restrict freedom of association have been passed at both the Commonwealth and State levels. Examples include the Menzies legislation banning the Communist Party ${ }^{59}$ and recent NSW legislation to control union payment of membership dues to political parties. ${ }^{60}$

\footnotetext{
54 See for example the Resolutions Adopted at the Australian Constitutional Convention, Parliament House, Brisbane, 29 July to 1 August 1985, 312. application of the rules of natural justice to the Governor in Council, see Roebuck $v$ Borough of Geelong West (1876) 2 VLR (L) 189; Shire of Kowree $v$ Shire of Lowan (1897) 19 ALT 143.

57 The responsibilities for representatives may also meet the test of conventions as propounded by authors such as Marshall. See Geoffrey Marshall, Constitutional Conventions (Clarendon Press, 1984).

58 ibid 9.

59 Australian Communist Party $v$ Commonwealth (1951) 83 CLR 1.

60 See the Election Funding, Expenditure and Disclosures Act 1981 div 2A, 4A, ss 87, 95E, 96D-E; Unions NSW $v$ NSW [2013] HCA 58.
} 
Whether or not Mayo's responsibilities of representatives are now recognised as conventions, some judges have recognised elements of the responsibilities of representation, though not the responsibilities themselves. Their Honours have focused on the words in ss 7 and 24 that require a direct choice by the people of senators and members (respectively) as imposing limits on the legislature and the government. Accordingly, the legislature and government may not limit a free choice among the available candidates in an election, nor the freedom of political communication.

Several High Court decisions illustrate the scope of these limits. In describing the constitutional system of representative government, the High Court in Lange observed that 'the elections to [the Parliament] must be free, with all that this implies in the way of freedom of speech and political organisation' ${ }^{61}$ In Mulholland, Gleeson CJ maintained

that the choice required by the Constitution is a true choice with 'an opportunity to gain an appreciation of the available alternatives' and that a ballot paper that discriminated in favour of a government candidate 'might so distort the process of choice as to fail to satisfy the test' laid down in the Constitution. ${ }^{62}$

In Langer, the High Court upheld the system of full preferential voting, ${ }^{63}$ where voters number their ballot paper sequentially in accordance with their preference for candidates. Brennan CJ affirmed the validity of preferential voting on the grounds that it provided 'a method of freely choosing members of the House of Representatives' from amongst the available alternatives and 'permits a voter to make a discriminating choice among the candidates for election to the House of Representatives' ${ }^{64}$ In sum, the rules for making collective decisions are to be found in a variety of legal sources, including the Constitution and legislation. Some political practices have not yet been recognised as constitutional conventions, whilst other legal rules have not been fully developed.

\section{Legislative rights recognised and protected as constitutional rights}

I now turn to my second issue: how legislative rights may be recognised and entrenched by the Constitution. The so-called democratic rights which draw upon the Chartist movement in the United Kingdom, and that movement's legacy in countries such as Australia, have been expressly recognised in either

61 Lange v Australian Broadcasting Corporation (1997) 189 CLR 520, 559 (quoting Birch).

62 Mulholland v Australian Electoral Commission (2004) 220 CLR 181, 191-2.

63 Commonwealth Electoral Act 1918 (Cth) s 240.

64 Langer $v$ Commonwealth (1996) 186 CLR 302, 317. 
the Australian Constitution or in electoral legislation. There is contention over whether the rights are merely recognised in legislation, or may also now be protected by the Constitution.

This issue arose in relation to the Commonwealth Electoral Act's regulation of electorate sizes. The argument that ss 7 and 24 requiring a direct choice by the people requires equal electoral sizes in Commonwealth legislation was rejected by a majority of the High Court in McKinlay. ${ }^{65}$ At best, some judges in McKinlay and McGinty ${ }^{66}$ made obiter dicta statements that these provisions prohibit gross disparities in electorate size or other forms of electoral inequality. At some point such disparities could not be regarded as a direct choice by the people. Nonetheless, the Commonwealth Electoral Act now requires equality of electorate sizes, plus or minus ten per cent. ${ }^{67}$

More recently, members of the High Court have referred to a constitutional protection of the right to vote and participate in the political life of the community. The constitutional protection of the right to vote has been controversial. Professor Twomey, relying on Kiefel $\mathrm{J}$ in Rowe, has argued that ss 7 and 24 do not give rise to a personal right to vote. ${ }^{68}$ Professors Blackshield and Williams maintain that the requirement for a direct choice of representatives by the people in ss 7 and 24 arguably supports an implied right to vote. ${ }^{69}$ In this part, I briefly address two questions in relation to this controversy. First, what form of constitutional protection has been accorded to the right to vote by a majority of the High Court? Second, what is the relationship between the constitutional protection and legislation?

The Federal Parliament has enacted the franchise, which refers to a statutory right to vote. The Parliament has a plenary constitutional power to enact laws for elections and for the qualifications of electors. ${ }^{70}$ The first federal electoral act provided a franchise for all adult male and female persons qualified to vote. ${ }^{71}$ However, it excluded, on the basis of race, Aboriginal people, Torres Straight Islanders and persons of African and Asian descent. ${ }^{72}$ These disqualifications

\footnotetext{
65 Attorney-General (Cth); Ex rel McKinlay v Commonwealth (1975) 135 CLR 1.

66 McGinty $v$ Western Australia (1996) 186 CLR 140.

67 Commonwealth Electoral Act 1918 (Cth) s 59(10).

68 Anne Twomey, 'Rowe v Electoral Commissioner — Evolution or Creationism?' (2012) 31(2) University of Queensland Law Review 181, 196.

69 Tony Blackshield and George Williams, Australian Constitutional Law and Theory (Federation Press, 5th ed, 2010) 375.

70 Australian Constitution ss 8, 10, 29, 30, 31, and 51(xxxvi).

71 Commonwealth Franchise Act 1902 (Cth) s 3.

72 ibid s 4 provided: 'No aboriginal native of Australia Asia Africa or the Islands of the Pacific except New Zealand shall be entitled to have his name placed on an Electoral Roll unless so entitled under section fortyone of the Constitution.' This was replaced by the Commonwealth Electoral Act 1918 (Cth) s 39(5).
} 
were not removed until the early 1960s. ${ }^{73}$ The universal franchise now means that the legislative right to vote is conferred without restrictions based on race, gender and property. It was not until the 21 st century that the High Court decided whether or not the Constitution protected the universal franchise.

The recognition of constitutional protection of the right to vote was accepted by Gleeson CJ in Roach ${ }^{74}$ and French CJ, Gummow, Crennan and Bell JJ in Rowe. In Roach the High Court considered a challenge to legislation that banned all prisoners voting.

In Roach, the Chief Justice concluded 'that ... the words of ss 7 and 24, because of changed historical circumstances including legislative history, have come to be a constitutional protection of the right to vote' ${ }^{75}$

His Honour drew on the philosophy of the universal franchise to define the meaning of the right to participate in the political life of the community: ${ }^{76}$

Because the franchise is critical to representative government, and lies at the centre of our concept of participation in the life of the community, and of citizenship, disenfranchisement of any group of adult citizens on a basis that does not constitute a substantial reason for exclusion from such participation would not be consistent with choice by the people.

He accepted that a substantial reason required 'a rational connection with the identification of community membership or with the capacity to exercise free choice' ${ }^{77}$ In this case, his Honour concluded that the legislative ban on all prisoners voting was arbitrary because it did not distinguish non-serious from serious offences; only serious offences would warrant disenfranchisement. ${ }^{78}$

He noted that the rationale for 'the exclusion from the franchise' must be 'related to the right to participate in political membership of the community' ${ }^{79}$ Chief Justice Gleeson expressly referred to this right, defined broadly, regarding it as protecting the right to vote, which is one of the political rights of citizenship, which in turn provides for full membership of the community. His focus in the

73 Commonwealth Electoral Act 1961 (Cth) s 4 repealed s 39(5) of the 1918 Act; Commonwealth Electoral Act 1962 (Cth) s 2 removed s 39(6) a provision which restricted enrolment by Aboriginal people.

74 Roach v Electoral Commissioner (2007) 233 CLR 162.

75 ibid 174

76 ibid. Interestingly, in addressing the legislative ban on all prisoners voting in this case his honour said: 'Since what is involved is not an additional form of punishment, and since deprivation of the franchise takes away a right associated with citizenship, that is, with full membership of the community, the rationale for the exclusion must be that serious offending represents such a form of civic irresponsibility that it is appropriate for Parliament (177) to mark such behaviour as anti-social and to direct that physical separation from the community will be accompanied by symbolic separation in the form of loss of a fundamental political right.' Roach $v$ Electoral Commissioner (2007) 233 CLR 162, 176-7.

77 ibid 174.

78 ibid.

79 ibid. 
judgment, though, was on the right to participate as protecting the right to vote, which he regarded as a fundamental right. However, the Chief Justice's acceptance of the constitutional protection of the right to vote was not adopted by the other judges in Roach.

In Rowe, the existence of the right to vote was again considered by the High Court. In dissent, Kiefel $\mathrm{J}$ argued that ss 7 and 24 did not give rise to a personal right to vote. Her Honour construed the view of Gleeson CJ as a reference to 'an incident of universal adult suffrage, rather than an individualised view of "the franchise"". ${ }^{80}$ However, none of the majority judgments in Rowe adopted her approach. In fact, Chief Justice Gleeson's reference to the 'Constitutional protection of the right to vote' was quoted with approval by four judges French CJ, Crennan, Gummow and Bell JJ. ${ }^{81}$ Moreover, each advanced their own distinct understanding of the constitutional protection of the right.

French CJ recognised that ss 7 and 24 conferred rights on the whole people of the Commonwealth. This is because the right to vote was of concern to all the people ${ }^{82}$ and individual voting rights and duties to enrol are made in aid of a direct choice, required by ss 7 and $24 .{ }^{83}$ Chief Justice French quoted Gleeson CJ's views to justify the irreversible evolution of 'chosen by the people' as protecting the universal adult-citizen franchise. Justices Gummow and Bell noted that

legislative development always was to be overseen by the imperative of popular choice found in ss 7 and 24 of the Constitution ... One result is explained in the following passage from the reasons of Gleeson CJ in Roach $v$ Electoral Commissioner: ... [That] the words of ss 7 and $24 \ldots$ have come to be a constitutional protection of the right to vote.

Justice Crennan expressly recognised that the relevant words of ss 7 and 24 have always constrained Parliament' ${ }^{\prime 4}$ and, in Gleeson CJ's words, 'have come to be a constitutional protection of the right to vote'.$^{85}$ This, she said,

mandates a franchise which will result in a democratic representative government ... that is, a franchise free of arbitrary exclusions based on class, gender or race. To recognise that ss 7 and 24 mandate a democratic

80 Rowe v Electoral Commissioner (2010) 243 CLR 1, 127.

81 Gleeson CJ, Crennan, Gummow and Bell JJ.

82 Rowe v Electoral Commissioner (2010) 243 CLR 1.

83 ibid.

84 ibid, 107.

85 ibid. 
franchise, for the purposes of the popular elections which they prescribe, is to recognise the embedding of the right to vote in the constitutional imperative of choice by the people of parliamentary representatives. ${ }^{86}$

In sum, each judge in the majority referred to the constitutional protection of the right to vote, rather than a requirement or incident of representative government. In a recent review of Roach and Rowe, the Federal Court in Holmdahl $v$ Australian Electoral Commission (No. 2$)^{87}$ held that the Constitution conferred a public right to vote, not a personal right to vote. ${ }^{88}$ Justice Gray quoted with approval Justice McHugh's view in Langer: ${ }^{99}$

The 'rights' conferred by the section are given to 'the people of the Commonwealth' - not individuals, although by necessary implication a member of the public may bring an action to declare void legislation that is contrary to the terms of s 24 or what is necessarily implied by it. Whether or not a member has been 'chosen by the people' depends on a judgment, based on the common understanding of the time, as to whether the people as a class have elected the member. It does not depend on the concrete wishes or desires of individual electors.

Thus a person has a legal entitlement to enforce the public right. Presumably they are acting as representatives of the people of the Commonwealth. However, the right to vote is only conferred on individual persons as members of 'the people'. It is only a right exercised by the people as a class. Due to this complexity the distinction between personal and public right may prove difficult to discern in theory and application. While Justice Gray provided a persuasive opinion, he omitted to quote directly from Chief Justice Gleeson in Roach. His honour preferred Justice Kiefel's characterisation in Rowe of the Chief Justice's approach. Thus Gleeson CJ's justifications relied on by the majority in Rowe were not fully explored in Holmdahl. ${ }^{90}$ The precise nature of the constitutional protection of the right to vote remains contentious. But there is now, at least, clear judicial support for a constitutional protection of the right to vote.

The judgments of the majority in Rowe are of significance to the emergence of an interpretive relationship between the Constitution and longstanding legislation. The High Court's discussion of the relationship is of particular importance to an understanding of the regulatory limits of the Constitution. The aspects of that relationship that will be considered are the effect of the Constitution on legislation and the effect of legislation upon the Constitution. Special

86 ibid 117 (emphasis added).

87 Holmdahl v Australian Electoral Commission (No 2) [2012] SASCFC 110.

88 ibid, 125 Kourakis CJ and Sulan J concurred with Grey J.

89 Langer $v$ The Commonwealth (1995) 186 CLR 302, 342-43; see also, Langer $v$ The Commonwealth (1995)

186 CLR 302, 349 (Gummow J).

90 Leave to appeal to the High Court from the Federal Court in Holmdahl was denied on 12 April 2013. 
attention will be given to the idea of 'permeability' between the Constitution and legislation: the use of constitutional principles as interpretive tools for the direct or indirect protection of rights under legislation and the applicability of legislative provisions as normative principles to enhance the constitutionally prescribed system of representative and responsible government. ${ }^{91}$

My inquiry will focus upon the openness and potential flow of normative principles between the Constitution and legislation. It is important to note that while there is a permeability between these two instruments, the Constitution is supreme law and is not in any way dependent for its authority upon legislation. The possibility for an interpretation that strengthens the right to vote will be emphasised.

A legislative limit on the implied right to participate was at issue in Rowe, where the Court considered an amendment to the enrolment procedures. ${ }^{92}$ Since 1983, Commonwealth legislation provided that after the election was called, there would be a grace period of seven days to enrol for the first time, or to transfer enrolment if a person had changed their address. In 2006, legislation removed the grace period for new enrolments entirely, and reduced the period to three days for transfer of enrolments. ${ }^{93}$ The Electoral Commission estimated that reinstatement of the seven day grace period might affect approximately 100,000 people who lodged claims in the seven day period after the writs were issued. A majority in Rowe held that the amendment was invalid.

\section{Effect of the Constitution on legislation}

Four justices ${ }^{94}$ accepted that the right to vote was protected by the Constitution and regarded it as a limit on the legislative power of the Commonwealth. Chief Justice French held that the Australian Electoral Act provisions for grace periods of seven days for enrolment and 3 days for transfer of enrolment could not be restricted due to the 'collateral damage to the extent of participation by qualified persons'.${ }^{95}$ Even though some people failed to fulfil their duties under the Act, limiting their own opportunities, the damage was still a detriment 'of concern to

\footnotetext{
91 This definition is derived from the definition advanced by Craig Scott in an article in which he puts forward his definition of permeability as 'one means of giving practical legal effect to the abstract doctrine of interdependence which has, thus far in its lifespan, existed as little more than a rhetorical slogan'. Craig Scott, 'The Interdependence and Permeability of Human Rights Norms: With Special Reference to the International Covenants on Human Rights' (1989) 27 Osgoode Hall Law Journal 769, 771.

92 Rowe v Electoral Commissioner (2010) 243 CLR 1.

93 See Commonwealth Electoral Act 1918 (Cth) see especially s 102 (4AA) which were amendments made by the Electoral and Referendum Amendment (Electoral Integrity and Other Measures) Act 2006 (Cth). See also ss 101, 102(4) and 115 of the Commonwealth Electoral Act 1918 (Cth).

94 French CJ, Gummow and Bell JJ, and Crennan J.

95 Rowe v Electoral Commissioner (2010) 243 CLR 1, 22.
} 
the whole Commonwealth' ${ }^{96}$ In sum, he saw the legal effect of the amendment as diminishing the opportunities for enrolment and transfer of enrolment that existed prior to their enactment.

Justices Gummow and Bell believed the method of choice adopted by the legislative amendment failed as a means to what should be the end; that is, making elections as expressive of popular choice as practical considerations properly permit — popular choice being guaranteed by ss 7 and $24 .{ }^{97}$ They maintained that ' $[\mathrm{t}]$ he position then is reached that the 2006 Act has the practical operation of effecting a legislative disqualification from what otherwise is the popular choice mandated by the Constitution.' ${ }^{98}$ Their Honours also adopted a substantive view of the right, rejecting the argument of the Commonwealth that enrolment was merely a procedure, because it affected the rights of electors.

Justice Crennan accepted that 'the centrality of the franchise, to a citizen's participation in the life of the community and membership of the Australian body politic, was recognised in Roach' ${ }^{99}$ Her Honour also maintained that 'persons' had a 'right to participate in choosing parliamentary representatives', against which her Honour assessed the challenged legislation. ${ }^{100}$ She said:

It can be accepted that the impugned provisions ... operate to disentitle or exclude persons (otherwise legally eligible) from the right to vote and the right to participate in choosing parliamentary representatives for the State and Subdivision in which they reside. It can also be accepted that achieving and maintaining Electoral Rolls of integrity is a purpose which is compatible with ss 7 and 24 .

Her Honour held that the Amendment Act was not appropriate or necessary to protect the integrity of the Electoral Rolls. Moreover, 'to seek to discourage a surge of late claims for enrolment by disentitling or excluding those making them [under the Amendment Act] constitutes a failure to recognise the centrality of the franchise to a citizen's participation in the political life of the community'.$^{101}$

Thus their Honours recognise three different norms protecting participation and voting. The franchise may not be limited in a way that is detrimental or damaging to participation by 'qualified persons', ${ }^{102}$ or by 'disqualifying', 'disentitling' or 'excluding' of citizens, and should enhance the popular choice to participate in elections to the maximum extent that is practical.

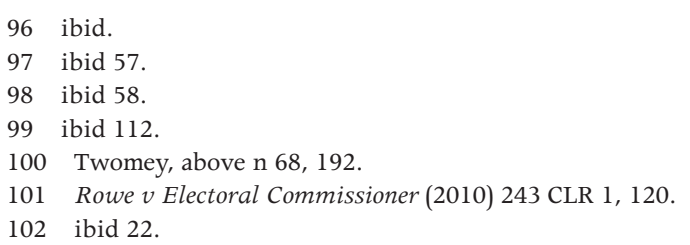




\section{Effect of legislation on the Constitution}

Significantly, it appears that the meaning of the constitutional text is in part defined by reference to legislation. In Rowe, French CJ explained that the universal franchise had become part of the content of the constitutional concept of 'chosen by the people' in ss 7 and 24. He maintained that this constitutional content was developed according to the common understandings of the time, which his Honour said was best expressed in 'durable legislative development[s]' . Justices Gummow and Bell maintained that legislative objectives may give effect to constitutional requirements: 'Section 245(1) states that it "shall be the duty of every elector to vote at each election". This legislatively stated duty furthers the constitutional system of representative government by popular choice. ${ }^{103}$ Thus legislative rights to participate may augment or permeate into the meaning of a direct choice by the people in ss 7 and 24. In Rowe, this occurred in two ways: first, the recognition of the right to a seven day grace period for enrolment and a 3 day transfer of enrolment after the election was called; and second, a right to a grace period for failure to enrol or transfer enrolment at a later time. The first grace period became constitutionally entrenched, and the second justified that entrenchment. Chief Justice French, Gummow and Bell JJ referred to s 101 of the Commonwealth Electoral Act 1918 (Cth), which imposes an obligation to enrol and transfer enrolment. ${ }^{104}$ If a person fails to comply, a criminal sanction is imposed, except where a person sends or delivers a late claim for enrolment or transfer to the Electoral Commissioner. Chief Justice French noted that the penalty provisions 'are designed not to punish, but to encourage maximum participation by persons qualified to vote'. ${ }^{105}$ Justices Gummow and Bell believed that the provision was designed to encourage maximum enrolment. ${ }^{106}$ The legislation encouraging maximum participation or enrolment was in the context of grace periods. It followed, in French CJ's words, that these durable legislative developments were a declaration of the common understanding of the right to vote and to participate in the political decisions of the community. ${ }^{107}$

The permeability of norms between the Constitution and legislation has significance for other legislative rights and freedoms mentioned in this chapter but not currently recognised as protected by the Constitution. Significantly, the so-called democratic rights or the 'rights of representatives' which give effect to a choice by the people have endured in legislation. The majority judgments

\footnotetext{
103 ibid 50.

104 Commonwealth Electoral Act 1918 (Cth) s 101.

105 Rowe $v$ Electoral Commissioner (2010) 243 CLR 1, 29.

106 ibid 58.

107 Justice Crennan's consideration of the effect of legislation on the Constitution was different to the other majority judges. Her Honour refers to the history of the franchise more generally, rather than focusing on legislative developments. The colonial franchises by federation, she noted, were designed to produce democratic lower houses, providing the genesis for the understanding of the constitutional protection given to the right to vote.
} 
in Rowe offer approaches that may see further democratic legislative rights protected. However, it is notable that the protection given by the majority to the right to vote pertained to the denial of individuals' opportunities to participate in an election. Not all voting methods may attract such protection: compulsory or preferential voting, which are concerned with Parliament's choice of electoral system, are one example. ${ }^{108}$

\section{Conclusion}

The High Court has now recognised a constitutional protection of the right to vote and participate in the political life of the community. The permeability of norms between the Constitution and legislation helps us better understand the nature and scope of that right. However, it has been argued that there is a broader conception of the right to participate in collective decisions which is recognised in constitutional principles, augmented by legislation and possibly constitutional conventions. This includes participation in legislative and executive decisions, not just voting in elections. Whether or not this broader right is recognised by the courts, it will remain of the utmost significance to the practice and proper functioning of Australian constitutional democracy.

\footnotetext{
108 The view that compulsory voting was required by the Constitution was expressly rejected in Rowe by Hayne and Kiefel JJ: Rowe v Electoral Commissioner (2010) 243 CLR 1, 75, 131; see also Heydon at [313]. Moreover, it may be inferred from Brennan's judgment in Langer that preferential voting is constitutional, though not necessarily required. See also Holmdahl v Australian Electoral Commission (2012) 277 FLR 101.
} 
This text taken from Law and Democracy: Contemporary questions, edited by Glenn Patmore and Kim Rubenstein, published 2014 by ANU Press, The Australian National University, Canberra, Australia. 